\title{
The Effect of Brand Awareness, Social Media Marketing, Perceived Quality, Hedonic Motivation, and Sales Promotion Towards Consumers Intention to Purchase in Fashion Industry
}

\author{
Regina Shwastika ${ }^{1}$ Keni Keni ${ }^{1,2^{*}}$
}

\begin{abstract}
${ }^{1}$ Master of Management Program, Universitas Tarumanagara, West Jakarta, DKI Jakarta, Indonesia, 11440
${ }^{2}$ Faculty of Economics and Business, Universitas Tarumanagara, West Jakarta, DKI Jakarta, Indonesia, 11470

*Corresponding author. Email: keni@fe.untar.ac.id
\end{abstract}

\begin{abstract}
This research was conducted to investigate the effect of brand awareness, social media marketing, perceived quality, hedonic shopping motivation, and sales promotion towards purchase intention on the fashion industry. Descriptive research was used and this study was included in a cross-sectional study where the data collection period was only carried out within a certain time. The questionnaire was distributed online using Google Form and every statement in the questionnaire is using five points Likert scale. The total sample was 154 respondents who live in Greater Jakarta, aged between 17-35 years old, and have purchased brand X products. Convenience sampling was used and all data were analyzed using the Partial Least Squares - Structural Equation Modelling (PLS-SEM) approach. The results have shown that there is a positive significant relationship between brand awareness, perceived quality, and sales promotion on consumer purchase intention while social media marketing and hedonic shopping motivation insignificant on purchase intention. In addition, the most significant factor that affects consumers' intention to purchase is sales promotion. Moreover, the firm could get benefit by formulating its brand management strategy in order to attract more consumers who intend to buy and could be more competitive over the other competitors.
\end{abstract}

Keywords: Purchase intention, Brand awareness, social media marketing, perceived quality, hedonic shopping motivation, sales promotion

\section{RESEARCH INTRODUCTION}

In the beginning, when the internet was discovered, only a few people were able to use and utilize it. Along with computer technology advances to be easier and more practical to use, internet access is spreading rapidly throughout the world and internet users are increasing in number. Previously the internet was only used for communication and spreading information, but now the internet has been used as a tool for promotion and selling online. People used to buy and sell goods in conventional stores so customers have to come directly to be able to get the desired item. While nowadays these activities can be done online, sellers do not need to spend a lot of money to rent space for the store and buyers do not need to come in person and spend a lot of time. This phenomenon is an innovation in which sellers could use social media platforms such as Instagram, Facebook, and other marketplaces to promote their products for free. On the other hand, prospective buyers can also view products offered by sellers through this platform and access them for free anywhere and anytime.

The most purchased items online by the majority of people in Indonesia are clothes with a percentage of $14.6 \%$ [1]. In addition, the most often generation that access the internet in Indonesia is millennials and the most purchased product by the millennial is clothing with a percentage of $24.6 \%$ [2]. The percentage above means that the interest of the millennials in Indonesia towards fashion is very high. Moreover, the high sales of fashion goods in Indonesia have made lots of new brands appear. The more clothing products exist on the market, the tighter the competition will be. In order to survive the existing competition, companies need to increase sales figures. So, to be able to increase sales, companies need to know and have a better understanding of the factors that affect the purchase intention of consumers [3]. 
Furthermore, brand awareness, brand association, perceived quality, and brand loyalty are factors that affect purchase intention [4]. Brand awareness is an important variable and affects purchase intention because it has to embed the image of its product in the minds of consumers. Increasing brand awareness will make consumers purchase products more often [5]. Furthermore, the higher the brand awareness, the higher the purchase intention. In addition, perceived quality is able to influence consumers to pay a higher price for a product or service that has a distinct difference compared to other products [6]. Therefore, this is the main reason why consumers are willing to buy these products or services even though they are quite expensive. In other words, quality has a more important value than the price of the product itself.

Moreover, it is widely recognized that hedonic shopping motivation has a very influential power in encouraging purchase intention [7]. So, the higher the hedonic shopping motivation, the higher the purchase intention. Currently, many companies use social media to market and advertise a product. The use of social media itself is to get more business opportunities where consumers are exposed to the message of a brand and provide more inspiration. Through marketing activities by utilizing social media, companies need to build a brand consistently to increase purchase intention [8]. Besides, sales promotion is also a factor that influences purchase intention in the fashion industry [9]. Sales promotion aims to arouse desires and encourage consumers to try new products and provide many benefits for consumers. So, this study aims to test empirically whether brand awareness, social media marketing, perceived quality, hedonic shopping motivation, and sales promotion can influence purchase intention.

\section{LITERATURE REVIEW AND HYPOTHESES DEVELOPMENT}

\subsection{Brand Awareness}

Tritama and Tarigan [10] stated that "brand awareness is the ability of a potential buyer to recognize and recall a brand as part of a particular product category." Knowledge of a brand underlies consumers to judge a particular product. According to Shahid, Hussain, and Zafar [11] "brand awareness is the measurement of the accessibility of a brand in the memory of the customer and we can measure it through brand recall." Brands will be fast and easy to remember when they are embedded in the hearts and minds of consumers. Based on the above definition, it can be concluded that brand awareness is a picture that is in the minds of consumers of a product that has been seen or heard and can recognize the product again when given a hint.

\subsection{Social Media Marketing}

The definition of social media marketing according to Choi et al. [12] is "engaging with customers through SNSs is commonly known as social media marketing and brings several benefits to companies, such as creating word of mouth, positively affecting customer equity, enhancing customer loyalty to the company, and increasing purchase intention of the company's products or services." Moreover, social media is a communication tool that connects sellers and customers. Felix et al. [13] explained that "social media marketing is an interdisciplinary and cross-functional concept that uses social media to achieve organizational goals by creating value for stakeholders." Therefore, it can be concluded that social media marketing is a series of marketing process starting from increasing consumer awareness, interest, consideration, intention, evaluation, purchase, loyalty to advocacy through providing attractive information to consumers and also a two-way interaction to maintain a relationship with consumers.

\subsection{Perceived Quality}

The impression of quality affects consumers in choosing an item and generally, consumers have a tendency to buy something which has good quality. According to Shahid, Hussain, and Zafar [11] "perceived quality means how much a brand fulfills the expectations of its consumers". Asshidin, Abidin, and Borhan [14] said that "perceived quality is defined as a consumer's evaluation of a brand's overall excellence based on intrinsic (performance and durability) and extrinsic cues (brand name)." The longer a product can be used, the better the perceived quality of the item will be. Based on the definition above, it can be concluded that perceived quality is an impression or action in interpreting the good or bad of an item or service that is felt by consumers to provide a comprehensive picture and understanding.

\subsection{Hedonic Shopping Motivation}

According to Roux and Maree [15], the definition of hedonic shopping motivation is "fun-seeking, playfulness, leisure, excitement, spontaneity, social involvement and enjoyment." A person's desire to shop is influenced by many factors. Yu, Zhang, and Liu [16,] defined hedonic shopping motivation as "a source of enjoyment and pursue something new, emotional satisfaction, and symbolic meanings of features." Someone's needs for entertainment varies from one another. Based on the above definitions, it can be concluded that hedonic shopping motivation is someone's desire to shop which is influenced by emotions and aims to obtain entertainment which is considered as something that interesting, fun, and can be a pleasure in itself. 


\subsection{Sales Promotion}

Kotler and Amstrong [17] defined sales promotion as "short-term incentives to encourage the purchase or sale of a product or service." Sales promotion plays a very important role in shopping. Moreover, Perreault, Cannon, and McCarthy [18] stated that sales promotion is "a reference to those promotion activities - other than advertising, publicity, and personal selling - that stimulate interest, trial, or purchase by final customers or others in the channel." The more often sales promotions are used, the higher the sales figures. So, it can be concluded that sales promotion is a tool designed to attract consumers' attention and give influence to consumers to purchase goods where usually discounts are given within a certain time or tend to be short.

\subsection{Purchase Intention}

Gautam and Sharma [19] said that "purchase intentions refer to the possibilities of purchases made by consumers in near future." Companies need to identify what factors make consumers have the intention to buy a product. The meaning of purchase intention according to Kim and Ko [8] is "combination of consumers' interest in and possibility of buying a product." Based on the definition of the experts above, it can be concluded that purchase intention is the possibility of consumers to have something they want and influenced by interest so consumers buy the product in the end.

\subsection{The Effect of Brand Awareness on Purchase Intention}

When consumers have awareness of a brand, consumers could easily remember the characteristics of that brand. The more familiar the consumer is with a brand, the easier it will be for the brand to appear in consumers' memories. Therefore, a transaction will not occur if consumers do not have high brand awareness of a product. In other words, it can be concluded that the higher the brand awareness, the higher the purchase intention. Furthermore, brand awareness has a positive and significant effect on purchase intention [4][20][21]. Based on the explanation above, the first hypothesis (H1) in this study is:

H1: There is a positive and significant effect of brand awareness towards purchase intention

\subsection{The Effect of Social Media Marketing on Purchase Intention}

Having an interest in social media marketing has a good impact or influence on the company [19]. This is an effective way of exploring what consumers need and want. Moreover, social media is used to interact directly between companies and consumers [22]. Marketing activities using social media have received more attention from companies because they can reduce marketing costs, increase profits, share information, build a wider business network and build better relationships with consumers in the long term. Companies that use social media to market their products are also able to encourage the purchase intensity of the products being marketed. Therefore, there is a positive significant effect between social media marketing on purchase intention [19][22][23]. Based on the explanation above, the second hypothesis $(\mathrm{H} 2)$ in this study is:

$\mathrm{H} 2$ : There is a positive and significant effect of social media marketing on purchase intention

\subsection{The Effect of Perceived Quality on Purchase Intention}

Usually, consumers tend to give a good impression of a product quality if consumer perceptions are positive. The higher the perception of the goods', the higher the chances of consumers' willingness to purchase. Therefore, it could be said that a consumer's perception is influenced by the quality of a product [24]. Consumers' perceptions of the product's quality vary from one consumer to another. This subjective impression is seen from a consumer's point of view of the product or service quality and can influence consumer choices [4]. Thus, perceived quality has a positive and significant effect on purchase intention [4][24][25]. Based on the explanation above, the third hypothesis (H3) in this study is:

H3: There is a positive and significant effect of perceived quality on purchase intention

\subsection{The Effect of Hedonic Shopping Motivation on Purchase Intention}

Consumers with different ethnic and cultural backgrounds have various motivations when it comes to shopping. Because of different habits, the reason for consumers to do shopping is different too. Some consumers like shopping because they consider it fun and entertaining, or because of its value and function. In addition, there was a significant influence between hedonic motivation on purchase intention [26][27]. Based on the explanation above, the first hypothesis (H4) in this study is:

H4: There is a positive and significant effect of hedonic shopping motivation on purchase intention

\subsection{The Effect of Sales Promotion on Purchase Intention}

The main function of sales promotion is to communicate with consumers and touch consumers' hearts. Sales promotion is used as the main way to lure consumers to quickly buy a more specific product or service in a short time. Sellers use various sales promotion techniques to 
attract buyers' attention and increase sales. The more often a brand provides sales promotion, the higher the consumer's purchase intention. Therefore, sales promotions have a significant influence on purchase intention [28][29][30]. Based on the explanation above, the last hypothesis (H5) in this study is:

H5: There is a positive and significant effect of sales promotion on purchase intention

\section{RESEARCH METHODOLOGY}

This study used descriptive research and could be categorized as cross-sectional research. Primary data is used because the data is obtained directly from the research subject by using a questionnaire. The process of distributing questionnaires to each respondent was carried out directly and online. The population in this study were all consumers of fashion clothing of brand $X$ and the sample is the millennial generation who have bought brand $\mathrm{X}$ products and are domiciled in Greater Jakarta. In addition, the sampling method used non-probability sampling with convenience sampling technique. The number of respondents that can be used as a sample in this study is 154 out of a total of 243 respondents. A total of 89 respondents could not be used because they did not meet the criteria. The data were analyzed by using PLS-SEM with SmartPLS 3.3.2 software. Moreover, in this study, there are two types of research variables, brand awareness, social media marketing, perceived quality, and hedonic shopping motivation are independent variables, while purchase intention is the dependent variable. Furthermore, 36 indicators were used in this study. The measurement of each indicator is used a five-point Likert scale, from strongly disagree, disagree, neutral, agree, and strongly agree with each value from 1 to 5 respectively.

\section{RESULTS \& DISCUSSIONS}

The data analysis technique in this study used the Partial Least Square-Structured Equation Modeling (PLS-SEM) approach using Smart PLS 3.3.2 software. Data analysis in PLS-SEM uses three test steps, namely the outer model (measurement models), inner model (structural models), and hypothesis testing. In addition, this study has a total of 154 respondents which the majority of respondents were women with a percentage of $68 \%$ while the percentage of male respondents was $31.2 \%$. Respondents aged $26-35$ years had the biggest percentage $(63 \%)$ while respondents aged $17-25$ years had a percentage of $36.4 \%$. Other results showed that the most of respondents have a profession as private employees (57.1\%), have an income of IDR 5,000,000 - IDR 9,999,999 (42.9\%), and have estimated spending on brand $\mathrm{X}$ products in three months of IDR 0 IDR 500,000.

After identifying the characteristics of the respondent, the outer model analysis was conducted to ensure that each indicator used in the study is valid and reliable. The minimum value for loading factor and the AVE value has to be more than 0.7 and 0.50 respectively as a validity requirement in the convergent validity analysis [31]. Then a discriminant validity was analyzed by looking at the Fornell-Lacker value and cross loading value. It can be said valid if the cross-loading value on the associated indicator is greater than any other cross loading value of the other indicator, whereas for Fornell-Larcker criterion is measured based on the AVE value of each construct must be greater than the highest correlation with other constructs [31]. The loading factor, AVE, cross loading and Fornell-Lacker values for all indicators in this study have exceeded the minimum value. After all the indicators met the validity requirements, a reliability test was carried out by looking at the composite reliability value (>0.6) and Cronbach Alpha $(>0.6)$ [31]. It can be seen in table 1 that all indicators in this study have met the requirements of the measurement method described above. Thus, all the indicators are valid and reliable.

The next step is to conduct an inner model analysis. It can be seen that the coefficient of determination $\left(\mathrm{R}^{2}\right)$ value is 0.668 . This means that the percentage of all independent variables that affect purchase intention in this study is $68.8 \%$. Then, the remaining $31,2 \%$ is influenced by other variables that are not taken to be examined in this study. In addition, the value of 0.467 from $\mathrm{Q}^{2}$ means that the variables in this study have strong predictive relevance and can predict the research model well. Moreover, the variables that have the greatest effect to the smallest effect $\left(\mathrm{f}^{2}\right)$ as a predictor in this study are sales promotion, then perceived quality, brand awareness, social media marketing, and hedonic shopping motivation.

Besides, the path coefficient value indicates that all variables in the study have a positive influence on purchase intention. The minimum significant value on t-statistic is $>1.96$ and $p$-value is $<0.05$. So, it can be seen in table 2 that brand awareness, perceived quality, and sales promotion have a significant effect on purchase intention, which means that $\mathrm{H} 1, \mathrm{H} 3$, and $\mathrm{H} 5$ are accepted. Meanwhile, social media marketing and hedonic shopping motivation have an insignificant effect on purchase intention, which means $\mathrm{H} 2$ and $\mathrm{H} 4$ are rejected.

The first hypothesis showed that $\mathrm{H} 1$ is accepted. This finding is consistent with previous research which confirmed that brand awareness has a positive and significant effect on purchase intention [4][20][21]. Consumers gain knowledge of a brand in two ways which are direct and indirect experiences. For direct experience, it is when consumers have used these goods or services, while the indirect experience is obtained by consumers through advertisements and marketing programs [32]. When consumers have a good awareness of a brand, usually consumers can easily recall the products' characteristics of the brand and it helps in increasing customer purchase intentions. Usually, if consumers already have a brand that they idolize, the consumer will have a higher purchase intention of the product [33]. Therefore, popular brands tend to be easier to recognize and distinguish from other 
competitors and will have higher purchase intentions compared to brands that have low brand awareness [4].

Table 1 Measurement \& structural model assessment results

\begin{tabular}{|c|c|c|c|c|c|c|c|c|}
\hline Variable & Indicator & $\begin{array}{c}\text { Loading } \\
\text { Factor }\end{array}$ & AVE & $\begin{array}{c}\text { Cronbach's } \\
\text { Alpha }\end{array}$ & $\begin{array}{l}\text { Composite } \\
\text { Reliability }\end{array}$ & $\mathbf{R}^{2}$ & $\mathbf{Q}^{2}$ & $f^{2}$ \\
\hline \multirow{4}{*}{$\begin{array}{c}\text { Brand } \\
\text { Awareness }\end{array}$} & BA1 & 0,864 & \multirow{4}{*}{0,739} & \multirow{4}{*}{0,883} & \multirow{4}{*}{0,919} & \multirow{4}{*}{ - } & \multirow{4}{*}{-} & \multirow{4}{*}{0,074} \\
\hline & BA2 & 0,835 & & & & & & \\
\hline & BA3 & 0,877 & & & & & & \\
\hline & BA4 & 0,862 & & & & & & \\
\hline \multirow{5}{*}{$\begin{array}{l}\text { Social Media } \\
\text { Marketing }\end{array}$} & SMM1 & 0,770 & \multirow{5}{*}{0,722} & \multirow{5}{*}{0,903} & \multirow{5}{*}{0,928} & \multirow{5}{*}{ - } & \multirow{5}{*}{ - } & \multirow{5}{*}{0,008} \\
\hline & SMM2 & 0,887 & & & & & & \\
\hline & SMM3 & 0,883 & & & & & & \\
\hline & SMM4 & 0,823 & & & & & & \\
\hline & SMM5 & 0,879 & & & & & & \\
\hline \multirow{5}{*}{$\begin{array}{l}\text { Perceived } \\
\text { Quality }\end{array}$} & PQ1 & 0,868 & \multirow{5}{*}{0,789} & \multirow{5}{*}{0,933} & \multirow{5}{*}{0,949} & \multirow{5}{*}{ - } & \multirow{5}{*}{ - } & \multirow{5}{*}{0,214} \\
\hline & PQ3 & 0,924 & & & & & & \\
\hline & PQ4 & 0,912 & & & & & & \\
\hline & PQ5 & 0,884 & & & & & & \\
\hline & PQ6 & 0,852 & & & & & & \\
\hline \multirow{8}{*}{$\begin{array}{l}\text { Hedonic } \\
\text { Shopping } \\
\text { Motivation }\end{array}$} & HSM1 & 0,842 & \multirow{8}{*}{0,715} & \multirow{8}{*}{0,944} & \multirow{8}{*}{0,952} & \multirow{8}{*}{-} & \multirow{8}{*}{ - } & \multirow{8}{*}{0,001} \\
\hline & HSM2 & 0,861 & & & & & & \\
\hline & HSM3 & 0,891 & & & & & & \\
\hline & HSM4 & 0,863 & & & & & & \\
\hline & HSM5 & 0,864 & & & & & & \\
\hline & HSM6 & 0,901 & & & & & & \\
\hline & HSM7 & 0,780 & & & & & & \\
\hline & HSM8 & 0,750 & & & & & & \\
\hline & SP1 & 0,838 & & & & & & \\
\hline & SP2 & 0,774 & & & & & & \\
\hline $\begin{array}{c}\text { Sales } \\
\text { Promotion }\end{array}$ & SP3 & 0,872 & 0,691 & 0,887 & 0,917 & - & - & 0,268 \\
\hline & SP4 & 0,902 & & & & & & \\
\hline & SP5 & 0,760 & & & & & & \\
\hline & PI1 & 0,855 & & & & & & \\
\hline & $\mathrm{PI} 3$ & 0,868 & & & & & & \\
\hline Purchase & PI4 & 0,879 & 0,717 & 0,901 & 0,927 & 0,668 & 0,467 & - \\
\hline & PI5 & 0,828 & & & & & & \\
\hline & PI6 & 0,803 & & & & & & \\
\hline
\end{tabular}

Table 2 Path coefficient and hypotheses testing results

\begin{tabular}{|c|c|c|c|c|}
\hline Hypotheses & $\begin{array}{c}\text { Path } \\
\text { Coefficient }\end{array}$ & t-Statistics & P-Values & Results \\
\hline Brand Awareness $\rightarrow$ Purchase Intention & 0,196 & 3,022 & 0,003 & Significant \\
\hline Social Media Marketing $\rightarrow$ Purchase Intention & 0,079 & 1,050 & 0,294 & Not Significant \\
\hline Perceived Quality $\rightarrow$ Purchase Intention & 0,351 & 5,315 & 0,000 & Significant \\
\hline Hedonic Shopping Motivation $\rightarrow$ Purchase Intention & 0,018 & 0,240 & 0,810 & Not Significant \\
\hline Sales Promotion $\rightarrow$ Purchase Intention & 0,372 & 6,386 & 0,000 & Significant \\
\hline
\end{tabular}

The second hypothesis showed that $\mathrm{H} 2$ is rejected. The results obtained in this study are contrary to previous studies which stated that social media marketing has a significant effect on purchase intention [19][22][23]. Moreover, a possible explanation for the differences of the research's results in this study with the results of other studies because the majority of respondents gave neutral answers to statements about social media marketing in the questionnaire. The other reason is there is too much information on the internet has become a challenge for the 
firm to be able to communicate and stay in touch with consumers. Therefore, to have a positive impact on purchase intention, communication efforts must be interactive and entertaining so that it is the job of marketers to be able to create content that attracts and entertains consumers [23].

The third hypothesis showed that $\mathrm{H} 3$ is accepted. This finding is consistent with previous research which confirmed perceived quality has a positive and significant effect on purchase intention [4][24][25]. The impression of quality can help consumers in assessing a product subjectively so that the product has its value in the eyes of consumers. Quality is the most important thing and has a big responsibility in terms of meeting needs and providing satisfaction to consumers. As the result, the perception of quality is a way for consumers to judge whether a product is good or bad by relying on their experience with goods or services that have been used. For consumers, perceived quality is the primary criterion for product appraisal and thus influences purchase intention. So, it can be concluded that consumers who have a positive quality impression of a product can increase purchase intention.

The fourth hypothesis showed that $\mathrm{H} 4$ is rejected. The results of this study are supported by the results of research conducted by Irshad and Ahmad [34] while other studies said otherwise [26][27]. The differences between the result of this study and the previous result's study can be caused due to differences in culture, habits, and mindsets possessed by respondents in this study. It can be seen that the majority of respondents gave neutral answers to the statements regarding hedonic shopping motivation on the questionnaire. Furthermore, due to the rapid development of technology, consumers have realized that in shopping, they only buy brands that are well known and following their needs. Thus, the company's desire to be more advanced than its competitors can be achieved by increasing the level of consumer desire to buy products owned by the company. The fifth hypothesis showed that H5 is accepted. This finding is consistent with previous research which confirmed sales promotions have a positive and significant effect on purchase intention [28][29][30]. Sales promotion carried out by brand $\mathrm{X}$ can attract consumer attention and increase purchase intention. It is proven by the majority of respondents agree to the statements regarding sales promotion on the questionnaire. Besides, most of the respondents agreed that the sales promotions provided by brand $\mathrm{X}$ were interesting and fun. This shows that sales promotion determines consumer purchase intentions. Furthermore, businesses in the fashion world must emphasize what factors make products more valuable and important to consumers. Therefore, sales promotion can provide a pleasant perception for consumers and that's why this business must bring consumers into a pleasant shopping situation.

\section{CONCLUSIONS \& IMPLICATIONS}

Based on the data analysis, the results of this study could be concluded that brand awareness, perceived quality, and sales promotion have a significant effect on purchase intention while social media marketing and hedonic shopping motivation insignificant on purchase intention. Moreover, this study provides a better understanding of companies regarding market trends and consumer behavior. In the competitive fashion industry, it is important to follow trends and know what consumers need continuously so the firm can create effective and efficient marketing. Besides, the company must be able to continue to increase consumers' brand awareness. These needs are considered because the fashion industry moves very quickly and competitively. In addition, the firm needs to bring up more informative and persuasive information in every content on social media and the website by providing entertaining content using visually appealing product images, highquality graphics, attractive fonts, eye-catching colors, unique captions, etc. So, in the end, the motivation of consumers to make purchase intentions is also higher.

Furthermore, the companies must take action to increase consumer confidence in their decision to buy brand $\mathrm{X}$ products and reduce anxiety about the possibility that consumers may have chosen the wrong brand. Thus, the company must be more interactive and innovative, to give a better impression of the company images in consumers' minds. The findings in this study can also provide insight for people who are interested in investing in the fashion industry. Marketers will be able to formulate the right marketing strategy to study an industry that is very competitive but also very profitable. Therefore, brand $\mathrm{X}$ needs to innovate continuously in providing promotions that can attract consumers to increase purchase intention. The firm has to conduct deeper market research regarding what kinds of motivation that influence consumers to have purchase intentions and requires good brand management in managing a large market share, to be able to survive the existing competition.

\section{LIMITATIONS \& SUGGESTIONS FOR FUTURE RESEARCH}

Comprehensive statistical data has been explained in this study, which allows further research to compare and to distinguish market trends and economic situations in various cities, countries, or even other generations. The differences in consumer behavior and preferences of different generations can also be evaluated in more detail. Future researchers can use other variables and also conduct qualitative studies to obtain in-depth information and knowledge about the needs and motives of consumers to make purchase intentions. Besides, this study uses a crosssectional design that is unable to describe changes in consumer attitudes over time. Therefore, future research can be carried out using a longitudinal design to obtain better results. Then, this study only focuses on the fashion 
industry, while consumer behavior may differ in other industrial contexts. Thus, further researchers can use various industries such as tourism, food, transportation, etc. The next researchers can also use the same variables but use different fashion brands as research subjects and use sample that is larger than this study can be used, to get a higher validity value.

\section{ACKNOWLEDGMENTS}

The authors would like to appreciate the LPPM, the Institution for Research and Community Service of Universitas Tarumanagara (Lembaga Penelitian dan Pengabdian kepada Masyarakat Universitas Tarumanagara) for financial support with contract No. 1641-Int-KLPPM/Untar/XII/2020. Gratefully thank Dr. Keni, S.E., M.M. for the support, advice, and for the time in supervising during the paper making process. We acknowledge the support received from all respondents who are willing to participate in filling out the research questionnaire. Further thank Dr. Indra Widjaja, S.E., M.M. as Head of Magister of Management Program, Universitas Tarumanagara who allow authors to conduct this research. Particular thank all friends, family, and the others who have helped the authors in completing this paper.

\section{REFERENCES}

[1] Asosiasi Penyelenggara Jasa Internet Indonesia, Laporan Survei: Penetrasi \& Profil Perilaku Pengguna Internet Indonesia, 2018. Accessed on: Oct. 23, 2019. [Online] Available: https://apjii.or.id/survei

[2] IDN Research Institute, Indonesia Millennial Report 2019, 2019. Accessed on: Oct. 23, 2019. [Online] Available: https://cdn.idntimes.com/content-documents/ indonesia-millennial-report-2019-by-idn-times.pdf.

[3] S. Bebber, G. S. Milan, D. D. Toni, L. Erbele, and L. A. Slongo, "Antecedents of Purchase Intention in the Online Context, Journal of Relationship Marketing, vol.16, no. 1, pp. 82-98, 2017. DOI: http://dx.doi. org/10.1080/15332667.2016.1242396

[4] J. E. Lee, M. L. Goh, and M. Nazri, "Understanding Purchase Intention of University Students Towards Skin Care Product," PSU Research Review: An International Journal, vol. 3, no. 3, pp. 161-178, 2019. DOI: https://doi.org/10.1108/PRR-11-2018-0031
[5] N. J. Khan, M. A. Razzaque, and N. M. Hazrul, "Intention of and commitment towards purchasing luxury products: A study of Muslim consumers in Malaysia," Journal of Islamic Marketing, vol. 8, no. 3, pp. 476-495, 2017. DOI: https://doi.org/10.1108/JIMA12-2015-0091

[6] U. Chakraborty, "The Impact of Source Credible Online Reviews on Purchase Intention: The Mediating Roles of Brand Equity Dimensions," Journal of Research in Interactive Marketing, vol. 13 no. 2, pp. 142-161, 2019. DOI: https://doi.org/10.1108/JRIM-062018-0080

[7] M. Y. C. Yim, S. C. Yoo, P. L. Sauer, and J. H. Seo, "Hedonic Shopping Motivation and Co-Shopper Influence on Utilitarian Grocery Shopping in Superstores," Journal of the Academic Mark Science, vol. 42, pp. 528-544, 2014. DOI: https://doi.org/ $10.1007 / \mathrm{s} 11747-013-0357-2$

[8] A. J. Kim and E. Ko, "Do Social Media Marketing Activities Enhance Customer Equity? An Empirical Study of Luxury Fashion Brand," Journal of Business Research, vol. 65, pp.1480-1486, 2012. DOI: https:// doi.org/10.1016/j.jbusres.2011.10.014

[9] F. U. Rehman, R. B. M. Yusoff, S. B. M. Zabri, and F. B. Ismail, "Determinants of Personal Factors In Influencing The buying Behavior of Consumers In Sales Promotion: A Case of Fashion Industry," Young Consumers, vo. 18, no. 4, pp. 408-424, 2017. DOI: https://doi.org/10.1108/YC-06-2017-00705

[10] H. B. Tritama and R. E. Tarigan, "The Effect of Social Media to the Brand Awareness of A Product of A Company," Communication and Information Technology Journal, vol. 10, no. 1, pp. 9-14, 2016. DOI: https://doi.org/10.21512/commit.v10i1.1667

[11] Z. Shahid, T. Hussain, and F. Zafar, "The Impact of Brand Awareness on the consumers' Purchase Intention," Journal of Marketing and Consumer Research, vol. 33, pp. 34-38, 2017. DOI: https:// doi.org/10.4172/2168-9601.1000223

[12] E. K. Choi, D. Fowler, B. Goh, and J. Yuan, "Social media marketing: applying the uses \& gratifications theory in the hotel industry," Journal of Hospitality Marketing \& Management, Vol. 25, no. 7, pp. 771-796, 2016. DOI: https://doi.org/10.1080/19368623.2016. 1100102

[13] R. Felix, P. A. Rauschnabel, and C. Hinsch, "Elements of strategic social media marketing: a holistic 
framework," Journal of Business Research, vol. 70, no. 1, pp. 118-126, 2017. DOI: https://doi.org/ 10.1016/j. jbusres.2016.05.001

[14] N. H. N. Asshidin, N. Abidin, and H. B. Borhan, "Perceived Quality and Emotional Value that Influence Consumer's Purchase Intention towards American and Local Products," Procedia Economics and Finance, vol. 35, pp. 639-643, 2016. DOI: https://doi.org/ 10.1016/ S2212-5671(16)00078-2

[15] I. L. Roux and T. Maree, "Motivation, Engagement, Attitudes and Buying Intent of Female Facebook Users," Independent Research Journal in the Management Sciences. vol. 16, no. 1, pp. 1-11, 2016. DOI: http:// dx.doi.org/10.4102/ac.v16i1.340

[16] H. Yu, R. Zhang, and B. Liu, "Analysis on Consumers' Purchase and Shopping Well-Being in Online Shopping Carnivals with Two Motivational Dimensions," Sustainability, vol. 10, pp. 1-18, 2018. DOI: https://doi.org/10.3390/su10124603

[17] P. Kotler and G. Armstrong, Principles of Marketing, United Kingdom: Pearson Education, 2018.

[18] W. D. Perreault, J. P. Cannon, and E. J. McCarthy, Essentials of Marketing: A Marketing Strategy Planning Approach. New York: McGraw Hill, 2014.

[19] V. Gautam and V. Sharma, "The Mediating Role of Customer Relationship on the Social Media Marketing and Purchase Intention Relationship with Special Reference to Luxury Fashion Brands," Journal of Promotion Management, pp. 1-17, 2017. DOI: https://doi.org/10.1080/10496491.2017.1323262

[20] R. B. F. I. Sidharta, N. L. A. Sari, and W. Suwandha, "Purchase Intention Pada Produk Bank Syariah Ditinjau Dari Brand Awareness Dan Brand Image Dengan Trust Sebagai Variabel Mediasi," MIX: Jurnal Ilmiah Manajemen, vol. 8, no. 3, pp. 562-578, 2018. DOI: http://doi.org/10.22441/mix.2018.v8i3.007

[21] A. Poulis, I. Rizomyliotis, and K. Konstantoulaki, "Do firms still need to be social? Firm generated content in social media," Information Technology and People, vol. 32, no. 2, pp. 387-404, 2019. DOI: https://doi.org/10.1108/ITP-03-2018-0134

[22] B. M. A. Almohaimmeed, "The Effect of Social Media Marketing Antecedents on Social Media Marketing, Brand Royalty and Purchase Intention: A Customer Perspective," Journal of Business and Retail Management Research, vol. 13, no. 4, pp. 146-157,
2019. DOI: https://doi.org/10.24052/JBRMR/V13IS04/ ART-13

[23] P. Laksamana, "Impact of Social Media Marketing on Purchase Intention and Brand Loyalty: Evidence from Indonesia's Banking Industry," International Review of Management and Marketing, vol. 8, no. 1, pp. 13-18, 2018. DOI: https://econjournals.com/index. php/irmm/ article/view/5838

[24] L. Yan, F. Xiaojun, J. Li, and X. Dong, "Extrinsic Cues, Perceived Quality, and Purchase Intention for Private Labels," Asia Pacific Journal of Marketing and Logistics, vol. 31, no. 3, pp. 714-727, 2019. DOI: https://doi.org/10.1108/APJML-08-2017-0176

[25] N. Norfarah, P. M. Koo, and A. K. Siti-Nabiha, "Private Label Brand Purchase Intention: A Malaysian Study," Global Business and Management Research: An International Journal, vol. 10, no. 1, pp. 197-215, 2018. DOI: http://www.gbmrjournal.com/vol10no1.htm

[26] D. P. Singh, "Online Shopping Motivations, Information Search, and Shopping Intentions in an Emerging Economy, " East Asian Journal of Business Management. vol. 4, no. 3, pp. 5-12, 2014. DOI: http://doi.org/10.13106/eajbm.2014.vol4.no3.5.

[27] M. Krithika and G. Rajini, "Buying Or Browsing: Motivation Behind Online Purchase Intention," Man In India, vol. 97, no. 22, pp. 1-7, 2017. DOI: https://www.researchgate.net/publication/323186392_B uying_or_browsing_Motivation_behind_online_purcha se_intention\#fullTextFileContent

[28] A. Y. P. Chang, "A study on the effects of Sales Promotion on consumer involvement and purchase intention in Tourism industry," Eurasia Journal of Mathematics, Science and Technology Education, vol. 13, no. 12, pp. 8323-8330, 2017. DOI: https://doi.org/ $10.12973 /$ ejmste/77903

[29] L. R. Ye and H. H. Zhang, "Sales Promotion and Purchasing Intention: Applying the Technology Acceptance Model in Consumer-To-Consumer Marketplaces," International Journal of Business, Humanities and Technology, vol. 4, no. 3, pp. 1-5, 2014. DOI: http://doi.org/10.30845/ijbht

[30] O. F. Santini, C. H. Sampaio, M. G. Perin, L. B. Espartel, and W. J. Ladeira, "Moderating Effect of Sales Promotion Types," Brazilian Administration Review, vol. 12, no. 2, pp. 169-189, 2015. DOI: https:// doi.org/10.1590/1807-7692bar2015140057 
[31] J. F. Hair, G. T. M. Hult, C. M. Ringle, and M. Sarstedt, A Primer Partial Least Squares Structural Equation Modeling, UK: SAGE Publications, 2017.

[32] I. S. A. Koliby and M. A. Rahman, "Influence Dimensions of Brand Equity on Purchase Intention Toward Smartphone in Malaysia," VFAST Transaction on Education and Social Sciences, vol. 15, no. 1, pp. 719, 2018. DOI: http://dx.doi.org/10.21015/vtess.v15i1. 478

[33] M. Q. Shabbir, A. A. Khan, and S. R. Khan, "Brand Loyalty Brand Image and Brand Equity: The Mediating Role of Brand Awareness," International Journal of Innovation and Applied Studies, vol. 19, no. 2, pp. 416423, 2017. http://www.ijias.issr-journals. org/abstract. php?article=IJIAS-16-237-03

[34] M. Irshad and M. S. Ahmad, "Impact of Consumers' Online Motivations on The Online Purchase Intentions: Mediating Role of Consumers' Attitude Toward Social Media Marketing," Business \& Economic Review, vol. 11, no. 3, pp. 89-112, 2019. DOI: https://doi.org/10. 22547/BER/11.3.4 